\title{
So, How Old Is Too Old: A Forced Reflection on the Meaning of Old Age
}

\author{
DEBRA SELLERS, PHD \\ School of Family Studies and Human Services, Kansas State University, \\ Manhattan, Kansas, USA
}

This first person narrative details an illuminating and personal insight that transpired for the author, a gerontologist. Her attitudes about growing older, the meaning of old age, and implicit ageist views are challenged during a chance encounter. This insight occurred in the most unlikely place-a racetrack - and during a time when she was certainly "off duty" as a gerontologist and thus, perhaps, most unprepared for the consequences of the interaction. The author is forced to reflect upon her own life and old age future, and is able to find serenity and peace in that vision.

KEYWORDS ageism, attitudes, old age

"Wow, this is one cool old guy," I thought to myself while standing in line behind him. It was easy to overhear his conversation with the woman inside the ticket counter - the old guy wanted to register. Please understand, when I say "the old guy," I am choosing descriptive language, just as if I were to say "the toddler" or "the teenager" or "the guy in the white shirt." No disrespect is intended.

The fact of the matter is that this guy was old. Just how old, I would find out later.

It was Open Track Night for the road course at Heartland Park (a race track) in Topeka, Kansas, and my husband was waiting to check in. My presence underscores only that my need to be a supportive wife won out over my fear of seeing him injured. For this night at least.

During Open Track Night, anyone with $\$ 80.00$, a car, a helmet—and the guts - can take their car onto the track and pretend that they are a real race car driver. It's fast. It's grueling. And, it's dangerous. People crash.

As a wife, I was there under protest. But as well, I am a gerontologist who studies aging. And I was intrigued by the older man in the line ahead of me wanting to register.

As a woman turning 40 and fighting the birthday blues, I was also charmed.

"So you're driving tonight, huh?" I said to him. The question was patently obvious, but it was all I could come up with on short notice. I didn't 
want him to get away without hearing his story.

He introduced himself as Larry, and this was his first time racing this car. He was however, a race fan, followed racing on television, and had been to several events. Larry had driven in that morning from Missouri. He'd come by himself-his wife had died 15 years ago. We chatted a bit, this old guy, my husband and I, until I realized that they both were distracted from what I thought was an immensely fascinating conversation. Each was itching to get their cars into the tech line. Ah yes, racing...

Again, I couldn't help myself. “Can I ride with you?" I asked him, not even giving my hubby a backward glance as I climbed into Larry's 2006, red, manual 6-speed Corvette Coupe.

We drove to the inspection point and the Vette passed without any trouble, and we headed up the hill, before parking our cars next to each other. While waiting for the drivers' meeting to start, we began chatting again. I wasn't surprised that more and more people found their way to our circle, joining us in the small section of shade where Larry was holding court.

Larry regaled us with his stories — of meeting Ron Fellows, a legendary race car driver and John Heinricy, a development engineer for GM; of building hospitals and courthouses throughout the Midwest; and of being a WWII veteran, whose service included the Battle of the Bulge.

Then the call for drivers to make their way to the pavilion came over the loudspeaker and Larry said he'd better get going; that he'd need more time to get up there then the young guys. As the drivers headed off, leaving me alone in a sea of silent iron, I thought about Larry and his life and my chance meeting with him that day. What made an old guy drive from Missouri by himself, to race a car that he'd never raced before? What was his motive? What possible reason could there be?

I looked across the parking lot at the cars waiting there- the Lotus, the Trans Am, the Volkswagen, my husband's Mustang - and then looked back at the drivers huddled under the pavilion, listening intently to their instructions, but also with feet swinging back and forth in nervous anticipation.

Seeing their keenness, I realized that, though older than the others, Larry's motive was exactly the same as the other drivers'. In fact, it was exactly the same as my husband's. The real question is: What would make anyone do this?

Well, I still don't completely understand the answer to that question, but I now know that young or old, it makes no difference.

Long before we met, my husband was a gearhead (for you non-car folk, this is the definition of someone who is obsessed with cars, speed, and racing). We've been married for 18 years now, and despite my numerous attempts, he is nothing if not a more serious one. Although my husband's interest continued to intensify, I held on to the belief that he would, at some point, outgrow what I considered a dangerous and adolescent preoccupation. My fascination that an old guy like Larry was at the track forced me to confront my attitudes about appropriate behavior and age.

Meeting Larry helped me to finally accept that my husband will continue to be a gearhead as he slowly transforms into my old guy. Perhaps this 
fact should have been obvious to me, as a gerontologist, especially after 18 years of consistent evidence. But that expanse between my professional study of aging and my personal life story within this particular realm had just been too great to cross. I was finally able to find comfort, even delight, in the thought that my husband will someday be just like Larry.

Larry let me glimpse my own future. How many people get to do that?

The novices, with Larry in the lead, sped out onto the track. He had an instructor with him, and he held his own. After taking the checkered flag, he pulled back into his spot next to us, got out, and started packing up.

"That's it?" We all asked. "You're done?" There were at least two, if not three, sessions left; but no, Larry was leaving us. He'd come and completed what he set out to do that day, and he wanted to get home before dark. "After all," he said to us, "when you're 90, you can't quite do what you've always done."

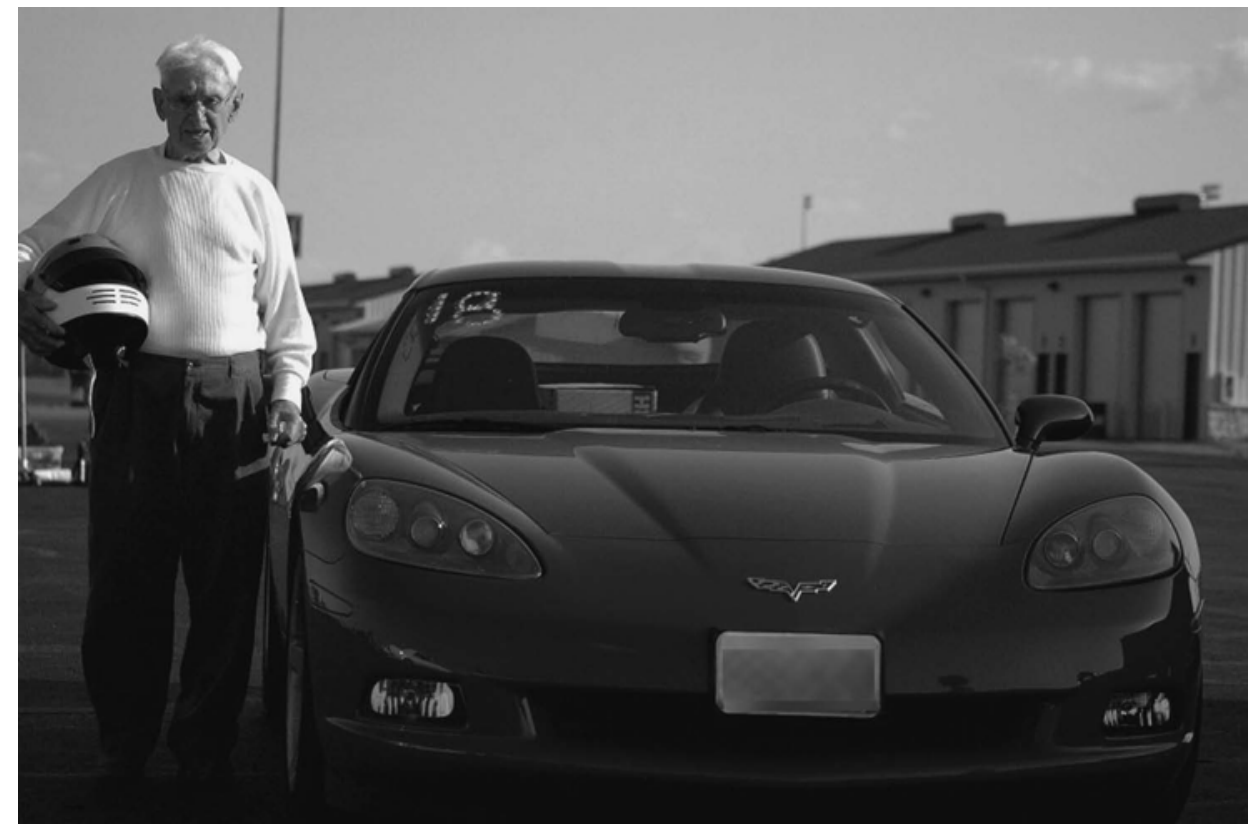

Larry at Heartland Park, Topeka

This essay was presented at the 2007 Cascade Conference on Successful Aging in Bend, Oregon. Photograph by Emily Zaitz. Address correspondence to Debra Sellers, School of Family Studies and Human Services, Kansas State University, Manhattan, KS 66506, USA. E-mail: dsellers@ksu.edu

Published in Journal of Aging, Humanities, and the Arts, 3:140-143, 2009 